\title{
Tax and Budgetary Measures during COVID-19 Crisis in Europe
}

\author{
Cristina Elena BADIU ${ }^{\star}$
}

\begin{tabular}{l}
\hline \multicolumn{1}{c}{ A R T I C L E I N F O } \\
\hline Article history: \\
Accepted August 2020 \\
Available online August 2020 \\
\hline JEL Classification \\
H25, H20 \\
Keywords: \\
COVID-19 crisis, Fiscal measures, \\
Unemployment rate, GDP, Public \\
debt \\
\hline
\end{tabular}

\begin{abstract}
A B S T R A C T
The COVID-19 crisis has caused two contradictory aspects: the population contamination, lockout of the medical system and increasing the number of deaths, and the economic crisis and bankruptcy. The fear generated by the lockout imposed by the crisis regarding the increase in number of bankruptcies and unemployment is the main reason why European governments are subsidizing business on a large scale. Also, all countries adopted diverse tax and budgetary measures in order to support the economy. The recovery from the crisis must be made considering the specifics of each economy, but the recovery and initial measures must coexist in order to ensure an appropriate framework for the return to the "afloat" condition.
\end{abstract}

(C) 2020 EAI. All rights reserved.

\section{Introduction}

The United Nations "was created not to bring heaven to earth but to save humanity from hell" - said Dag Hammarskjold - referring to the establishment of this organization after World War II (Parkins, 2020). To paraphrase, the fiscal measures embraced by the countries of the world to deal with the effects of the crisis are not aimed at "bringing heaven to earth, but saving humanity from hell" - at least economically. The same way as the world changed politically, economically, demographically, geographically after World War II, the COVID-19 crisis will bring about change in all aspects of life, as we perceive it now.

Governments have faced an extremely difficult and unexpected situation, which has generated different responses and measures. China initially tried to hide the causes and effects of the virus, after which it imposed a total lockdown of the affected area, America constantly accused China of the pandemic, instead of focusing on concrete actions, Europe closed its borders, but only after Italy and Spain has faced a large number of cases of contamination and death.

I have frequently come across the statement according to which the return after COVID-19 crisis will be in the form of "V", or "U" or even "W". However, there are also pessimists who claim that the future will not have any of these forms, but "more like a bathtub" (Foreman-Peck, 2020), i.e. it will take quite a long time for the economy to resume its normal operating parameters.

The fear generated by the lockout imposed by the crisis regarding the increase in number of bankruptcies and unemployment is the main reason why European governments are subsidizing business on a large scale. "No healthy business will go bankrupt because of the Corona Virus," said the German minister of economy in mid-March when he announced the extension of credit lines, cash securities and grants offered to German businesses, worth 750 billion euros (for the beginning). At the end of March, the German government suspended the obligation for insolvent companies to go bankrupt until September (and will probably extend it until March 2021) provided that it demonstrates that the lack of liquidity is due to the conditions generated by the COVID-19 crisis. France, Spain and other European countries have introduced similar facilities.

Such fiscal measures "buy time". Having experienced the 2008 financial crisis, when companies registered a sudden decrease in liquidity due to the lack of credit, in the current crisis they "have pumped" large sums in the economy to prevent the effects of ready cash shortage (DPA, 2020). But, unfortunately, in this crisis, this is not the only shortcoming created.

The coronavirus crisis has caused 2 contradictory and equally terrifying aspects:

- that of the population contamination, lockout of the medical system and increasing the number of deaths, on the one hand,

- that of the economic crisis and bankruptcy, on the other hand. 


\section{Action taken by governments of European states for companies and population and their cost}

European population trust in their governments differs a lot depending on the areas: north/ south, east/ west, according to the study conducted by "World Values Survey", quoted by The Economist journal on May 2nd, 2020 (Foreman-Peck, 2020b).

Thus the Swedes trust their government $60 \%$, the Italians $30 \%$ and the Romanians only $7 \%$, and this outcome is reflected in the fiscal measures adopted by states to support the economy and to overcome the economic, social and medical crisis, that is, the extent to which these measures meet the needs of the business environment and population, reflects that confidence.

The action taken by governments must take into account the following aspects:

- Sustaining an optimal cash flow;

- Providing the income of directly affected population

- Employee support.

Maintaining companies' liquidity through an optimal cash flow stands for the main objective of the embraced fiscal measures. The trend followed during the crisis and especially during the lockdown period was to provide companies with ready cash rather than to reduce taxes, considering the urgent nature of such action implementation.

It should not be overlooked that the set-up of emergencies in European countries and not only, was suddenly imposed, governments having perhaps only a few days at their disposal to adapt to this situation and then, there was necessary to provide this cash flow not to block off the economy to a larger extent (OECD, 2020a).

Also, most companies face the risk of insolvency and falling liquidity, concurrently with the prolongation of the crisis, which is why state support must be maintained and adapted to the needs of the business environment. Action to support business environment, according to a study by the OECD, could be:

- expediting the VAT refund;

- cutting down the VAT ratio;

- extension of payment terms, i.e. maturity of tax obligations,

- stimulating public investments;

- interest-free loans, or, rather, with state-subsidized interest, loans with government guarantees,

- postponement of the payment of bank instalments for companies and individuals,

- providing funds for the payment of salaries;

- exemption from payment of social insurance;

- stimulating consumption.

Such policies cost is obviously high and differs from one country to another, but the cost of the lack of action would have certainly been much higher, actually consisting in the loss of human lives (Figure 1).

Figure 1. The cost of fiscal measures in terms of percentage from GDP (2019)

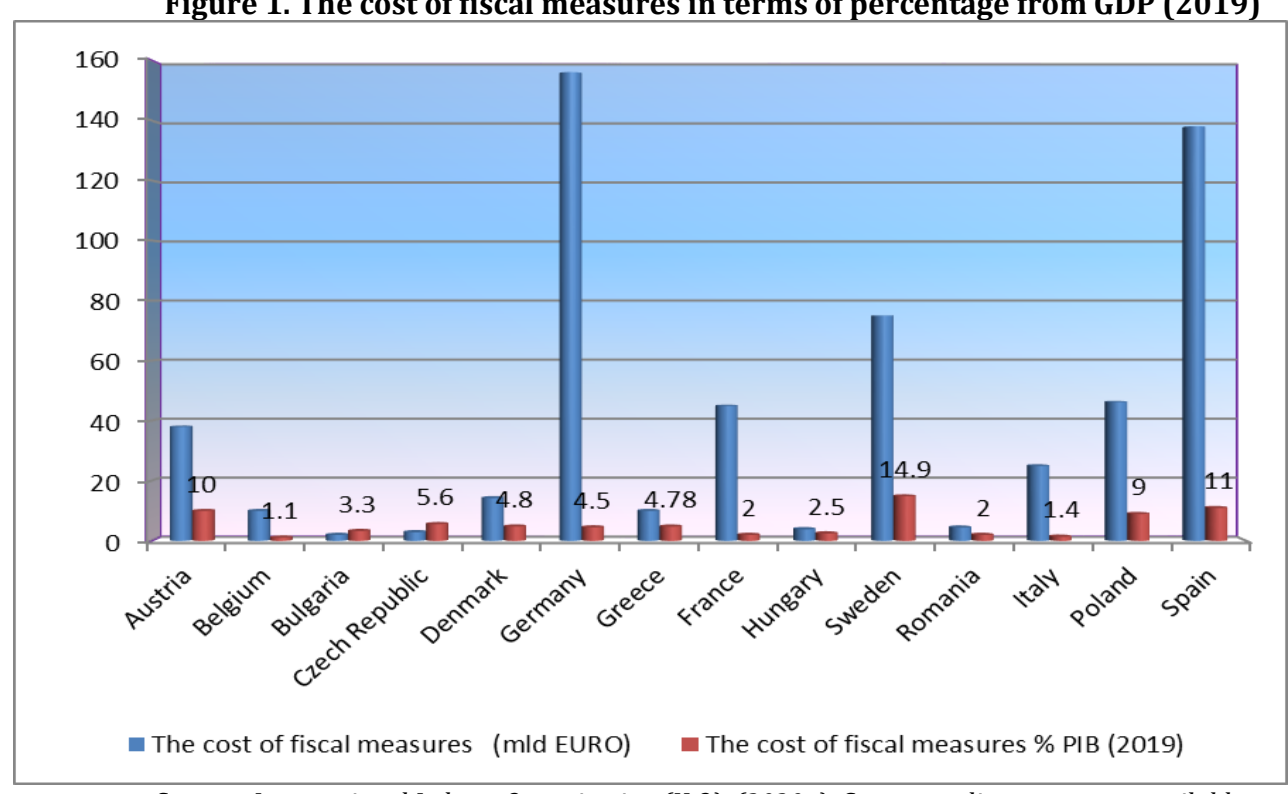

Source: International Labour Organisation (ILO). (2020a). Country policy responses, available at https://www.ilo.org/global/topics/coronavirus/country-responses/lang--en/index.htm accessed on June 5th2020. Country Economy (2020). GDP - Gross Domestic Product, Country GDP available at https://countryeconomy.com/gdp, accessed on June 5 th2020.

Florea, M. (2020). Covid-19: Guvernul adopta masuri fiscal-bugetare cu impact de 2\% din PIB, pentru sprijinirea mediului de afaceri, Manager.ro - Rentrop\&Straton, available at https://www.manager.ro/articole/ultima-ora-93/covid-19-guvernul-adopta-masurifiscal-bugetare-cu-impact-de-procente-din-pib-pentru-sprijinirea-mediului-de-afaceri-102984.html, accessed on June 5th 2020. 
Debts can have the effect of cutting own consumption and investment, which requires maintaining state support by means of fiscal action and incentives, but such measures must be geared towards stimulating consumption and investment.

Tax revenues should be significantly reduced, even over a period that could span several years, that's why the fiscal actions that have been adopted and will continue to be maintained must primarily support a solid increase of the economy. The tax level should be adjusted in the post-pandemic period, and this must be correlated with other tax policies in order to somehow soften the effects of the crisis (Figure 2). The longer the lockout lasts, the greater the economic and financial constraints of companies, even if there is liquidity obtained through the fiscal facilities granted.

Figure 2. Tax measures implemented by countries from the studied sample

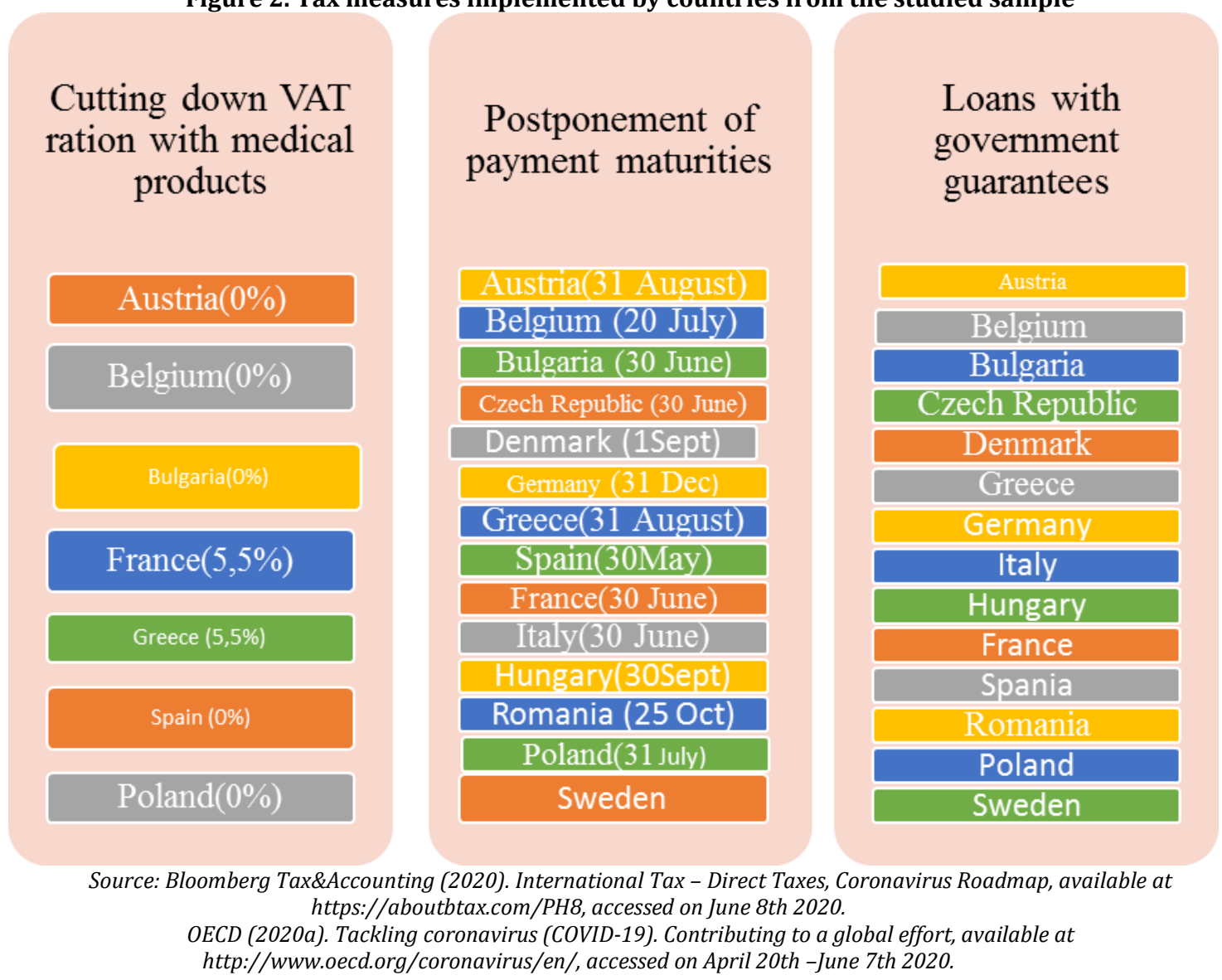

In the stage when we try to recover after the lockout related to the state of emergency, the fiscal stimulation must be maintained in order to build confidence in overcoming the crisis, in order to be able to stimulate consumption and investments. However, fiscal stimulation should be focused on the types of actions aimed to be stimulated, and their adoption must be done at the right time.

Financial aid granted during the lockout period can be considerable and therefore, as economies resume their course, it is necessary to try to increase public revenues by restoring the long-term sustainability of tax policies.

The fiscal action aimed at the population were:

- technical unemployment,

- paid medical leave,

- benefits granted to families with underage children.

However, such measures are enforced provided the compliance with certain conditions, for example, technical unemployment - unemployment benefits - provided the employees benefiting from this facility, keep their jobs when the facility ceases, in order to avoid redundancies.

The technical unemployment diagram was proposed and adopted in Germany during the financial crisis of 2008-2009, being subsequently taken over in other European countries and relates to unemployment benefits paid in full by the state for employees of companies that could not work during the lockdown period, as assistance for both for the employing companies - which were relieved from the burden of paying the employees - representing one of the fastest ways to cut expenses - but also for the employees who were able to obtain this allowance at a higher level than the standard level of unemployment, having the certainty of keeping their job (OECD, 2020a). 
At European level, in March 2020, when steps to prevent COVID-19 began to be enforced in the Member States of the European Union, the unemployment rate was 7.4\%, as compared to 7.3\% in February 2020 in the Euro area and 6.6\% in March as compared to 6.5\% in February 2020, according to Eurostat (Figure 3.a and 3.b).

Figure 3.a Unemployment rate, \%

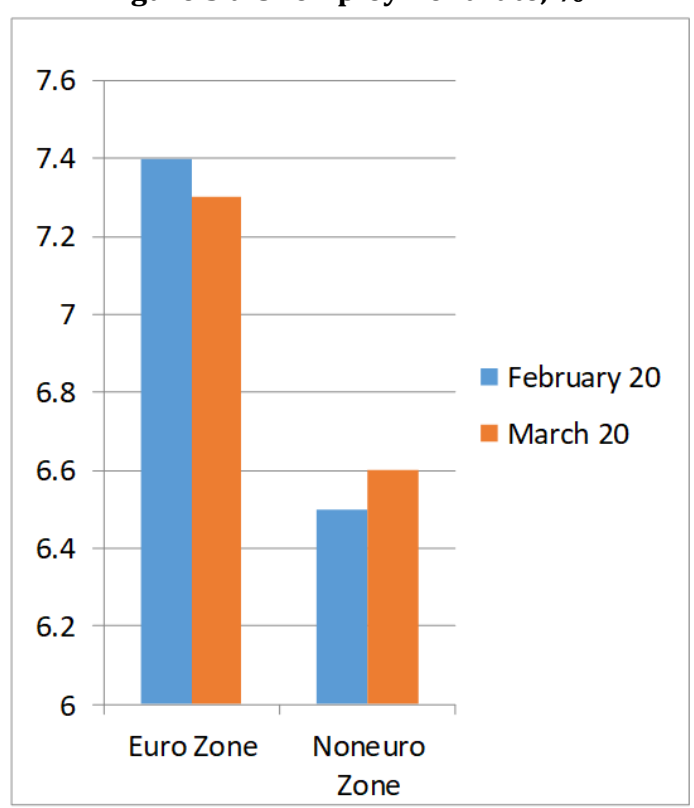

Figure 4.a. Unemployment rate, MM of people

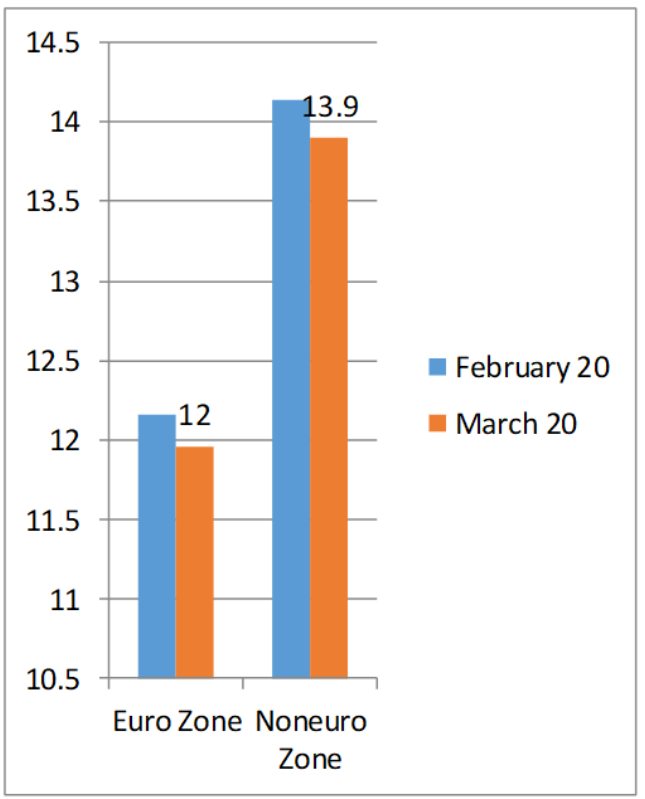

Source : Eurostat (2020a). Euro area unemployment at 7.4\%, 75/2020 - 30 April 2020, available at https://ec.europa.eu/eurostat/documents/2995521/10294732/3-30042020-CP-EN.pdf/05df809c-7eb8-10c7-efcf-35325c84f56e , accessed on May 20th 2020.
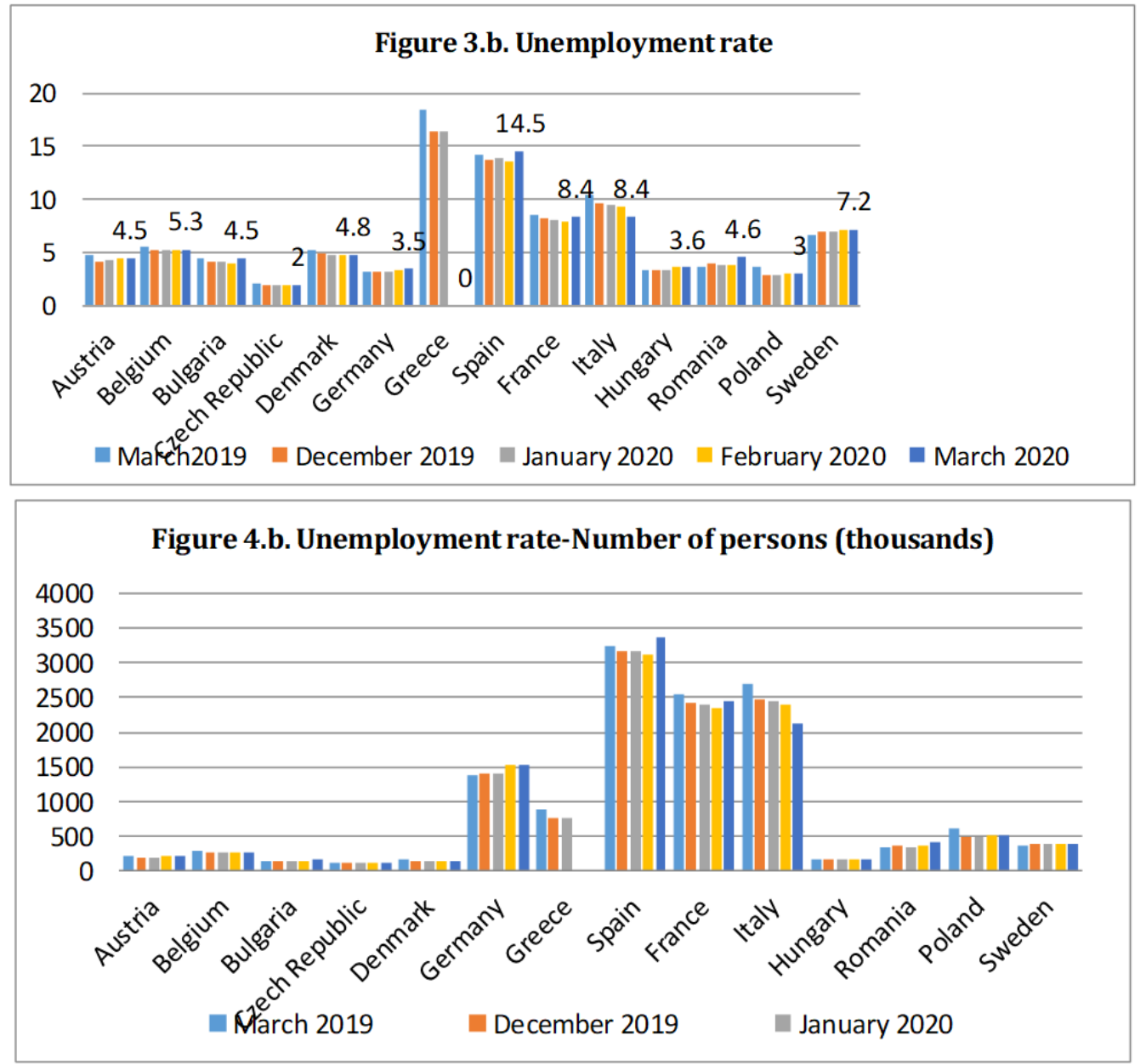

Source: Eurostat (2020b). Eurostat, news release euro indicators, available at 20 th 2020. 
Eurostat estimates that 14.141 million of people, out of which 12.156 million in the Eurozone, lost their jobs in March 2020. Compared to February 2020, the number of unemployed increased by 241,000 in the EU and by 197,000 in the Eurozone (Figure 4.a and 4.b).

\section{The sample of countries studied in terms of implemented tax measures}

The study was conducted on a number of 14 countries in the European Union, located in the main geographical areas.

From the Scandinavian peninsula we studied Denmark and Sweden, in Western and Central Europe we took the route for France, Spain, Germany, Austria and Belgium, which we considered countries having well developed economies, and then focused on a few countries with emerging economies from central Europe and Balkan peninsula.

\subsection{Countries from Scandinavian Peninsula}

Fiscal package measures differ within EU countries, but most are significant. Fiscal packages have implications in the public budgets and in relation to the public debt, and this impact differs from one country to another. The financing of the companies was done in terms of type of business in European countries.

For instance, in Denmark (OECD, 2020b), the package of measures amounts to 14.3 billion euros (4.8\% of GDP). The government has reached an agreement with municipalities to advance investments in energy rehabilitation and other similar initiatives worth 325 million euros. For companies that face large decreases in product demand and have made available at least $30 \%$ of workers (minimum 50 people), the state can cover $75 \%$ of the salary, but not more than 3,900 euros. The company should not dismiss those persons and possibly cover the difference of $25 \%$ of salary. The absorption rate is about $5 \%$ of the labour force (150,000 employees), and the cost amounts to about 1.3 billion euros.

Compensation was granted starting March 20th, as aimed for the payment of rents, bank interest, leasing instalments - for companies the activity of which cannot be carried out during the lockdown period, as well as all fixed costs of the business. The whole package of taken action amounted to 14.3 billion euros.

The other types of business have compensations depending on the decrease in turnover, as follows:

- a decrease of $80-100 \%, 80 \%$ of fixed expenses are compensated;

- a decrease of $60-80 \%, 50 \%$ of fixed expenses are compensated;

- a decrease of 40-60\%, 25\% of fixed expenses are compensated.

No support is granted for decreases in turnover of less than $40 \%$ or less than 25,000 crowns (3250 euros). The maximum amount granted to a company may not exceed 60 million crowns (10.8 million euros).

In order to benefit from these financial incentives, companies must apply to the Danish Business Authority. That application must include a forecast of the turnover decrease and a financial statement of fixed expenses.

The government decided to postpone by 4 months the contributions related to April, May and June, estimating an impact on liquidity of 11.7 billion euros and postponing the VAT payment by 30 days, which will generate liquidity of about 4.55 billion euros (ILO, 2020b).

Funds worth 4.64 billion euros have been made available to companies, for loans in which the state will cover guarantees to a percentage of $70 \%$, provided that small companies demonstrate a decrease in turnover of at least 30\%. The government will guarantee for foreign trade companies. Interruption of international trade will lead to a lack of liquidity and prevent insurance companies from operating to market requirements. That is why the government will provide guarantees of $€ 3.9$ billion euros to insure companies in 2020 .

The Danish government together with the Swedish one secured a loan of $€ 350$ million for Scandinavian Airlines (SAS), Denmark covering $50 \%$ of the guarantee.

Sweden (OECD, 2020b) has granted €75 billion in tax measures (14.9\% of GDP), representing the highest level of the scheme meant to reduce employees' working hours to $80 \%$ for 3 months, and the government will bear the costs almost entirely, i.e. $90 \%$ of the salary.

Profit tax due to 2019 will be deposited in a special reserve to be used in case of possible losses. Granting state aid of $€ 900$ million for the affected companies and financial support of $€ 25$ million for sole proprietors.

On April 30th, the government announced a 3.9 billion euro package to help loss-incurring companies. The amount can range between 22.5 and $75 \%$ of the fixed expenses of the company, excluding the salary costs related to March and April. Companies with a turnover discount of $€ 25,000$ for the previous tax year or a $30 \%$ reduction in turnover will be eligible. Almost 180,000 companies can qualify.

The state will also support $50 \%$ of rents for the most affected businesses - the effort being estimated at $€ 500$ million and $€ 45$ million to finance cultural activities.

The government, via the state agency Almi, provided grants worth $€ 270$ million, representing $0.06 \%$ of GDP, to allow small companies, but with development potential, to borrow more.

The Export Credit Agency has funds of $€ 18$ billion to finance export activities. The ceiling for insuring export activities against the risk of non-payment is $€ 45$ billion. 


\subsection{Surveyed European countries having a developed economy}

In Austria (IV, 2020), the set of fiscal remedy amounting to $€ 38$ billion (10\% of GDP, including government securities and postponement of payment deadlines) is gradually implemented.

Fiscal remedy relates to (ILO, 2020c):

- setting up an emergency fund for industries heavily hit by the crisis, providing grants for operating costs (€15 billion)

- government securities of $€ 9$ billion euros

- postponement of payment deadlines for population and companies, until September and relates to taxes due to March and April (€10 billion)

- Funds for those with reduced working hours (€10 billion) which include payment of social contributions for them and entrepreneurs as well, freelancers ( $€ 1$ billion).

Rapid supporting measures amounted to€4 billion and relates to (OECD, 2020b):

- Individual entrepreneurs and companies with less than 10 employees are supported by $€ 2$ billion, while a single entity can get up to €6000.

- Another $€ 2$ billion are offered to export companies and the measure wants to cover up to $15 \%$ of operational costs.

Companies in the tourism branch will get loans of up to €1 billion.

These loans are granted to cover liquidity needs and not to finance debt restructuring.

The "Harship Fund" of 2 billion euros was set up for individual businesses, artists, lawyers and for micro-enterprises, amounting to $€ 6000$ at most for a period of 3 months, to provide them with the ready cash they need to cope with financial stress and the lockdown period.

Larger companies have access to a state aid scheme, "Corona fund" of €15 billion.

A short work schedule designated as "Corona Kurzarbeit" was included, in force for 6 months, which allows employees short working hours ranging 10\% -90\%, $3+3$ months, where the employer pay them for the hours worked, the difference up to the full salary being borne by the state aid, according to the scheme: $90 \%$ (for a gross salary of $€ 1700$ ) from the net salary earned before the crisis, the financial burden being thus reduced for companies, provided there won't be any dismissals during the scheme period and a month thereafter.

In Belgium (ILO, 2020c), regional governments made available additional subsidies to the companies. For example, the Walloon Government provides assistance worth $€ 5,000$ to companies having been closed due to the pandemic and $€ 2,500$ to those that have reduced their activity. Banks grant loans to companies that urgently need liquidity with an interest rate of $2 \%$, over a period of 1 year, and the maximum amount is up to $€ 200,000$. For small-sized companies - loans amount to $€ 45,000$ with a maturity of up to 5 years.

The Flemish Government offers a premium of $€ 4000$ in addition to the $€ 160 /$ day aid for companies that are closed for more than 21 days. In addition, they have subsidies for companies incurring substantial losses. It also provides $€ 100$ million in loans to finance working capital. Companies scoring a $60 \%$ decrease in turnover can obtain a compensation of $€ 3000$ (OECD, 200b)

The Brussels Regional Government displays similar aid schemes. Companies staffing up to 50 employees which are bound to close, receive a $€ 4,000$ grant, whereas for small-sized companies the amount is $€ 2,000$. The value of loans with government guarantees made available to companies that have a significant decrease in business is €2000.

In France (Gouvernement, 2020), the joint actions of regional and national tax authorities aimed to ensure an effective way out of the crisis. The fiscal package cost for employees and companies, including the medical branch, is figure don April $3^{\text {rd }}$ around $€ 16.5$ billion, i.e. $0.7 \%$ of the related 2019 GDP. The main tax costs stand for the reduced work schedule (€8.5 billion), the steps taken in the medical system ( $€ 4.5$ billion) and the solidarity fund ( $€ 1.5$ billion) granted to small-sized companies and individual entrepreneurs. 2019 GDP.

Postponing maturity of tax and loan instalments payment can reach up to $€ 48.5$ billion, i.e. $2 \%$ of

The state has set up the Solidarity Fund to support declining activities, and such measures relate to either tax exemptions or preferential loans.

For March, April and May 2020, social contributions have been eliminated for the sectors inflicted by the pandemic, which will cost the French state 2.2 billion euros.

Thus, for tourism, €18 billion have been assigned to support restaurants, cafes, hotels, cultural and sports activities. Companies staffing up to 20 employees and achieving a turnover up to€ 2 million, will receive up to $€ 10,000$. Also, $€ 8$ billion will be invested in the automotive industry for the modernization of production lines, and 1 billion euros will be invested for development and innovation. A 4 billion euros fund has been set up to ensure the cash flow needed for start-ups.

Aid is granted for companies, between $€ 1500$ and 5000 for companies with a turnover of less than€ 60,000 and staffing less than 10 employees, depending on the seriousness of their actual situation. Government secured loans, up to $€ 300$ billion, will finance companies between March 16th and December 
31st, with a maturity of up to 6 years. The government guarantee covers $70 \%-90 \%$ of the loan amount, depending on the size of the company.

In Germany (OECD, 2020b), the emergency state was enforced on March 25th, when debt financing was supplemented by a budget of $€ 156$ billion, i.e. $4.5 \%$ of GDP, in order to provide the financial support needed for the state of emergency caused by COVID-19 and to cover the revenues decline, estimated at $€ 33.5$ billion (1\% of GDP).

The direct support for small-sized companies and individual enterprises with less than 10 employees is worth up to $€ 15,000$, the total funds assigned to this category being $€ 50$ billion. Starting July $1^{\text {st }}$, the VAT related to restaurants will be $7 \%$ for a period of 12 months. On April 22nd, the government decided that the rate of net earnings lost by employees whose working hours were reduced by $50 \%$, should be compensated by $70 \%$ of net earnings for those without children and by $77 \%$ for employees with children, for a period of 4 months. In the 7 th month, these compensations will increase up to $80 \%$ and $87 \%$, respectively.

Social contributions are paid $100 \%$ by employment agencies for the hours not worked by part-time employees (Eurostat, 2020e). The tax losses for 2020 will be able to be carried forward to previous financial years, in order to alleviate the burden of taxes for the current year (OECD, 2020c).

Providing liquidity for the affected companies was one of the objectives of the State Bank (KFW), which is run by the government and which is not a central bank, granting loans, not limited to a certain ceiling. Limiting loans according to the size of companies is a criterion that will adjust over time. Thus, the risk assumed by the government is increasing.

The volume of government guarantees amounted to $€ 2.5$ billion. On April 6, companies could receive loans immediately with $100 \%$ government guarantees from the central bank up to $25 \%$ of the 2019 turnover, capped at $€ 500,000$ for companies with 10-50 employees - and $€ 800,000$ for companies that have 50 and over 50 employees. The loans will be granted only on the basis of profitability, with an interest rate of $3 \%$ and a 10 years maturity.

In early June, Germany announced it would launch a €100billion stimulus package to counter the economic impact the coronavirus pandemic had created, and the announcement came after the EU released its $€ 750$ billion rescue plan for the 27 Member States, created to deal with the economic "carnage" produced by coronavirus (Markets Insider, 2020).

Italy (OECD, 2020b) provided €25 billion in tax facilities, €3.2 billion for the medical system and civil protection, €10.3 billion to protect employees' incomes, € 5.1 billion to increase the liquidity of companies and entrepreneurs and $€ 1.6$ billion for tax payment.

Employee aid consisted of:

$€ 5$ billion to supplement the scheme for the salaries of workers who have been fired and for those who do not meet the conditions for obtaining these benefits. $€ 13$ billion were assigned for parents with children up to 12 years. €130 million were allocated for the payment of those in lockdown and €900 million for granting of bonuses to those who continued to work at the headquarters of the companies. $€ 600$ granted to individual entrepreneurs and seasonal workers, with a total effort of $€ 2.3$ billion.

For those who lost their jobs, it was approved to suspend real estate loans instalments for one year. The total effort amounts to €400 million.

A $€ 500$ allowance / month for a period of 3 months, granted to entrepreneurs in the most affected cities. Small-sized companies in the most affected areas were granted the facility to suspend the payment of credit instalments, as well as the suspension of invoice payment for 2 months (March and April).

$€ 1.7$ billion have been assigned to provide charge-free loans to small businesses. The eligibility criteria have been extended, the costs reduced, the security fund reaching the value of $€ 5$ million and granted the suspension of the bank rates for small companies for 6 months (until the end of September).

Government guarantees amount to $€ 10$ billion for new loans granted to medium and large companies.

Measures have been taken to convert impaired loans, by converting deferred tax receivables, into tax credits for industrial and financial companies.

In Spain, the fiscal measures (OECD, 2020b) amount to €138.2 billion, of which €104.4 billion were ready cash made available to those in need. The main fields were:

For health $€ 4.3$ billion, policies aimed at the affected areas of the labour market and individual entrepreneurs €19.2 billions the policy of tax cuts is for companies and individual entrepreneurs €4.2 billion.

Measures to put the tax calculation basis in line with the current situation: use the direct estimation method for sole proprietors in order to calculate the revenue collected and VAT payment, which allow these payments adjustment to the actual income collected during the emergency period, the adjustment the income of taxes paid in advance by companies at the level estimated for 2020 . The effort amounts to $€ 1.1$ billion in liquidity. Exemption from the payment of social contributions for companies that have employees included in the ERTE program / temporary employment adjustment schemes), i.e. those technically unemployed, in proportion of $100 \%$ for the companies and $75 \%$ for other companies. SMEs (Small and medium-sized enterprises), 75\% of employer's social security contributions for other companies (UPB, 2020). 
The government provided financial support to small and medium-sized enterprises in the form of loans and grants to finance investments in digital equipment or home work-based solutions (the AceleraPyme program), worth $€ 250$ million. Possibility to postpone the payment of taxes, interest free, for 4 months, starting March 12th. Social contributions may be postponed for 6 months, interest free, for small and medium-sized enterprises - a€14 billion effort.

Tourism companies benefit from the suspension of the payment of instalments and interest related to loans, for 1 year, starting March, no prior application required to be submitted. $€ 400$ millions were made available to companies in the field of tourism in order to help revive this sector. Local authorities were allowed to use the budget surplus due to 2019 to finance social services and provide primary assistance to people with disabilities - an effort of€ 300 million. €1.2 billion were assigned from existing loan securities to guarantee loans to lessees and lessors (OECD, 2020a).

Consolidation of guarantees provided by CERSA in order to increase the guarantee local authorities guarantee capacity. Authorization of the Insurance Consortium to act in order to reinsure credit risk policies, to consolidate the channelling of resources for commercial loans. A zero-interest microcredit was adopted, worth up to 6 monthly rents, with a 10 years maturity, or a direct aid of $€ 900 /$ month.

ICO - the national development bank adopted a line of guarantees of $€ 100$ billion, which will cover guarantees for new and existing loans of small-sized companies and entrepreneurs to the extent of $80 \%$, and for the other types of companies, guarantees will be covered in proportion of $60 \%$ and $70 \%$. A 3-month moratorium on the payment of instalments on mortgage loans for private entrepreneurs affected by the crisis.

\subsection{European Countries with emergent economy}

In Poland, the fiscal measures adopted by the Government (OECD, 2020b) refer to a fiscal measures package of $€ 1293$ billion (2.9\% of GDP) from the state budget, $€ 1333$ billion (3.2\%) of GDP government guarantees for loans to small businesses and entrepreneurs individual (limited to a ceiling of $€ 122,200$ ). The fiscal package was expanded with additional measures to support spending of $€ 148$ billion, and on April 8th, the government launched a financial line of credit to companies of $€ 122$ billion to support companies and reduce the dismissal of employees. Approximately $60 \%$ of loans can be provided in the form of grants. This scheme consists of zero-interest loans for 3 years, $50 \%$ for companies with up to 9 employees, $25 \%$ for those with 10-49 employees and 25\% for large ones (OECD, 2020a).

For companies that have had a $40 \%$ drop in turnover, the government will pay $40 \%$ of the average salary in the economy, while the employer will bear the same percentage from the employee's salary, and he agrees to reduce the salary by $1 / 5$. This subsidy will be granted provided that the employer does not give up any employee.

Individual entrepreneurs will receive $50 \%$ of the average salary per economy for 2 months and farmers will get $50 \%$ of the same average salary throughout their hospitalization or lockdown. Exemption from social contribution payment for a period of 3 months for small-sized companies staffing up to 10 employees and individual entrepreneurs recording a drop of at least $50 \%$ in income since February. Companies staffing 10-49 employees benefit the same reduction, but limited to $50 \%$ of the total contributions (OECD, 2020a).

The National Bank of Poland (NBP) reduced the benchmark interest rate by 0.5 percentage points down to $1 \%$ in March and then reverting in April by a further $0.5 \%$. It relies on repo transactions to provide liquidity needed by commercial banks.

NBP also announced the purchase of Polish treasury securities on the secondary market, worth $€$ 136.8 billion ( $0.4 \%$ of GDP) on March 23rd, a day before the state of emergency was declared. The Minister of Finance, on the recommendation of the Financial Stability Committee, repealed the 3\% systemic risk buffer for the capital requirements of the commercial banks.

The government of Hungary (Trading Economics, 2020) announced fiscal measures amounting to 3.9 billion - $2.5 \%$ of 2019 GDP, which include temporary tax deduction, additional funds granted to the medical system, severance pay, subsidized investments. In addition, the government diminished by 2 percentage points employee social contributions for July-October 2020.

On April 6th, the government announced the $€ 116$ million Economic Protection Plan, aimed at restarting the economy. Hungary also received from the CRII - Corona Virus Investment Initiative, with the agreement of the European Council, € 861 million - $0.7 \%$ of GDP, funds to finance the expenses generated by the crisis in the medical system and to finance fiscal facilities granted to employees and companies (OECD, 2020a).

Temporary suspension of social contributions for the affected fields: tourism, restaurants, entertainment until June 30th and companies in the affected sectors can apply for tax reductions of up to $€$ 14,500 . Companies with incomes below $€ 145,000$, will not pay this tax, and for the others, the tax level is $0.1 \%$ and $0.4 \%$ respectively. 
The government has approved an investment support scheme of€ 140 million, which will provide grants of up to $€ 800,000$ to the affected companies in the field of services and production. Firms that are eligible must have a $25 \%$ loss in turnover, and the amounts from grants must be used in investments.

The loans made available to the business environment amounts to $€ 7.25$ billion, with government guarantee to an extent of $90 \%$ and interest rate of $0.1 \%$.

Banks can access long-term loans to provide liquidity to the real estate and capital markets. Thus, the Central Bank provided 232 million Euro credits with a maturity of 3 years (80\%) and 5 years (20\%), with an interest rate of $0.9 \%$.

The state aid is worth $€ 2$ billion in Bulgaria (OECD, 2020a).

-payment of $60 \%$ of employees' income by the state and payment of social contributions for the affected sectors, and employers the difference of $40 \%$ of income.

-extension of the maturities of the fiscal obligations until 30.06 .2020

-the government has assigned \$110 million to the Bulgarian Development Bank to provide interestfree loans worth $\$ 829$ to people on unpaid leave during a state of emergency (OECD, 2020b).

In the Czech Republic (Bloomberg Tax, 2020), the losses that will be registered in 2020 can be deducted from 2018 and 2019 profits, thus obtaining a refinancing from the Fiscal Administration.

Companies that have been forced to close caused by government action, may postpone rents payment for the period March 12th- June 30th, the payment being made subsequently for a period up to 2 years. The Ministry of Finance has estimated the increase of the budget deficit from 1\% expected in 2020, to $4 \%$. Both companies and the population can postpone their instalments for a period ranging 3-6 months. The credit fund made available to companies amounts to€180 million, i.e. $0.1 \%$ of GDP, with zero interest, and the maximum limit of a loan for a company is up to $90 \%$ of eligible expenses, for a maximum 2 years period (UNRR, 2020).

Greece- an attempt was made to divide equally between business and employees (OECD, 2020a). Companies in the affected fields receive a mix of loans and guarantees.

Fixed duties for companies and individual entrepreneurs in the impacted areas (tourism).

The level of measures is €6.8 billion ( $2 \%$ of GDP), of which 5 billion financed from the budget, and 1.8 billion from the European Special Fund.

The companies can apply for delayed payment of VAT until December 31st2020, provided that the object of activity has been affected by the COVID crisis.

$€ 400$ allowances were assigned for 155,000 people who have lost their long-term job. Also, $€ 600$ vouchers for professional retraining were granted to individual entrepreneurs for about 180,000 people. Also, for those included in this category, € 800 were granted as compensation for 520,000 people and employers staffing less than 20 employees $(90,000$ people).

The same amount of $€ 800$ was granted as compensation to employees whose employment contract was suspended, i.e. 1.7 million people, representing $81 \%$ of private sector employees. Reduction by $25 \%$ of the level of contributions paid to the state, provided their maturity is met (OECD, 2020b).

The state will support the level of interest on loans granted to companies, for March, April and May, provided that no employee is fired; also the suspension of the payment of the capital rate related to loans for companies affected by the crisis.

A program to support the economy has been adopted by the Greek Development Bank, in the form of government securities. The loans that will be guaranteed with these types of guarantees are those designed to the current capital, with a total exposure on the side of the Hellenic Development Bank capped at $40 \%$ of the volume of loans granted by financial institutions. This schedule reaches up to $€ 2$ billion.

Several tax measures have been adopted, including the tax deduction of corporate profit tax in Romania (OECD, 2020a). The state financed 75\% of the average salary in the economy for employees of companies affected by the crisis, employees who are technically unemployed.

One of the parents of children under 12, during the closing of schools, had the right to stay home with their children, receiving an allowance of $75 \%$ of the average salary in the economy, in such circumstances when working from home was not possible. Companies paying their 2019 profit tax in April, will get a bonus of $5 \%$ for large companies and $10 \%$ for small and medium-sized companies (OECD, 2020b). For companies that will pay their principal obligations by December 15th2020, the ancillary obligations related to the principal contributions of previous years will be exempted from payment.

The government has announced tax discounts, including VAT refunds expediting, audits suspending, suspension of enforcement of those in arrears until September 30th, amendments to the debt restructuring programs and figuring the calculation basis for companies' revenues. The government guarantee scheme has been extended to $€ 3.1$ billion - the maximum guarantee ceiling and a $€ 161$ million state aid scheme, including subsidized interest rates for small and medium-sized enterprises (PFM, 2020).

As of April 10th, Exim Bank, a state-owned bank, acting on behalf of the Romanian state, is allowed to issue insurance for short-term export loans in order to cover temporary non-transactional risks for EU and OECD countries. 
The National Bank of Romania (NBR, 2020) has reduced the reference interest rate from $2 \%$ to $1.75 \%$ and will continue to provide the necessary liquidity on the market and to maintain the exchange rate at a steady level, liquidity provision through credit institutions via REPO transactions and security purchase from the government, denominated in the national currency on the secondary market. On June 5th, the NBR entered into an agreement with the ECB for a $€ 4.5$ billion repo line, valid until the end of the year or as long as necessary. Bank rates can be suspended for a period of 6 months for companies and individuals affected by the crisis.

\section{The relationship between public debt and fiscal measures adopted by European states}

As can be seen in the above presentation, the effort is considerable for all countries. It is true that the value of incentives differs depending on the size of the population, but also on the economic power of the state, the degree of indebtedness, the level of public debt and its size in GDP (Figure 5).

We have conducted the survey below based on the weight of the public debt in GDP as an analysis criterion, to see if for countries with a high level of public debt, fiscal measures are more or less substantial than with others.

Figure 5. Public debt impact on GDP (2019) €millions
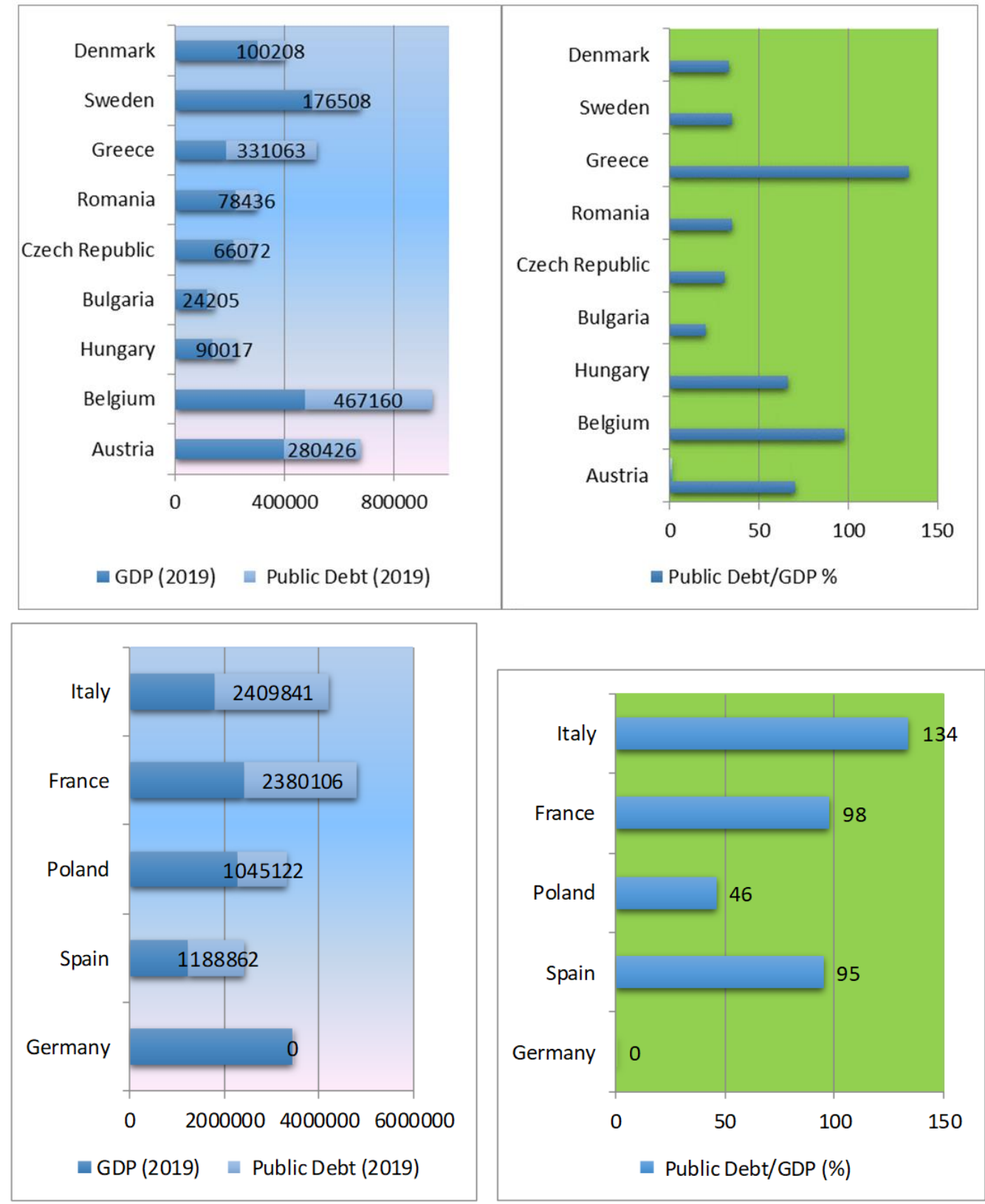

Information sources are the following web-sites:

Eurostat (2020d). EDP notification table, available at https://ec.europa.eu/eurostat/web/government-financestatistics/excessive-deficit-procedure/edp-notification-tables, accessed on May 16th2020.

OECD (2020a). Tackling coronavirus (COVID-19). Contributing to a global effort, available at http://www.oecd.org/coronavirus/en/, accessed on April 20th -June 7th 2020. 
Figure 6. Comparative analysis between public debt and the level of fiscal measures implemented

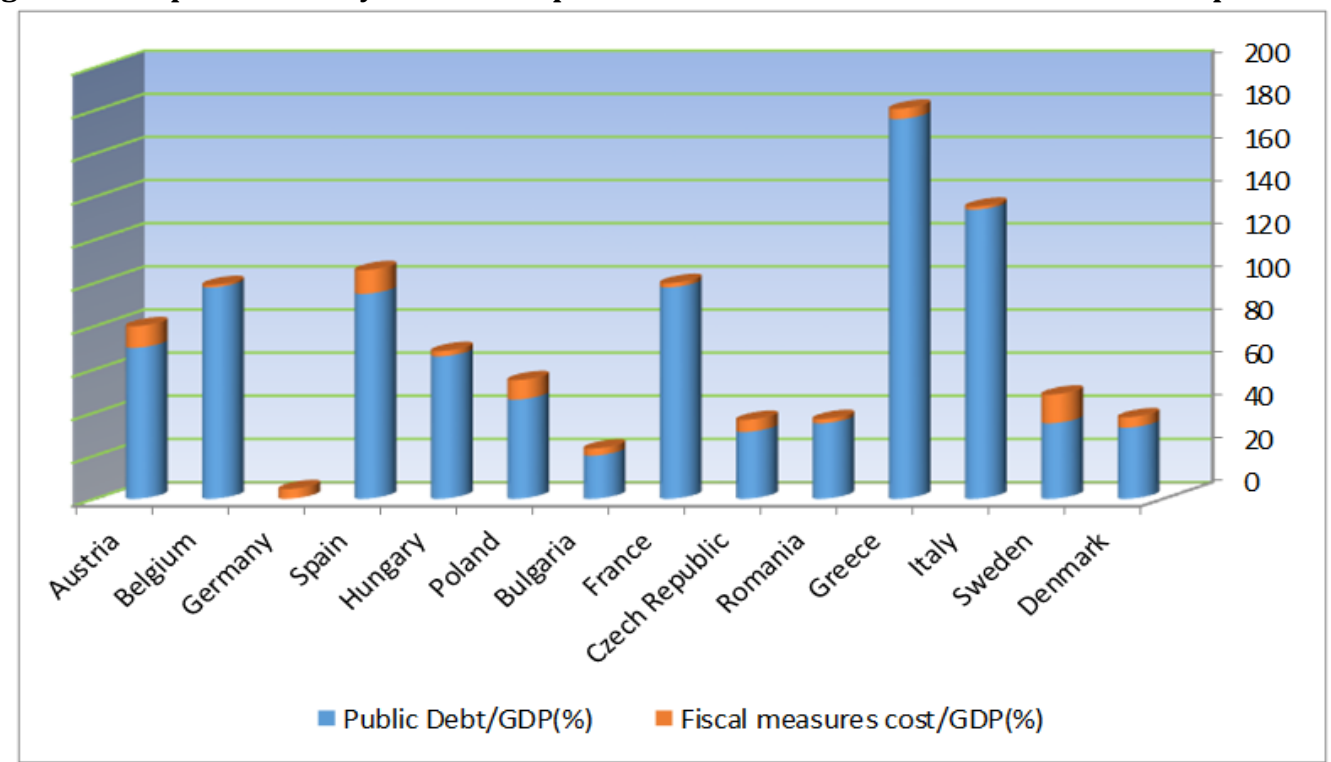

Source: Eurostat (2020e). Reporting of Government Deficits and Debt Levels, available at https://ec.europa.eu/eurostat/web/government-finance-statistics/excessive-deficit-procedure/edp-notification-tables, accessed on June 5th 2020.

From the data presented above (Figure 6), it cannot be said that there is a direct link between the country's indebtedness and the ceiling of fiscal measures. Greece, which is the country with the largest indebtedness of $176 \%$ of GDP, has granted fiscal facilities of 4,78\%, which is not the lowest level. Sweden, where debt is $35 \%$ of GDP, that is low, has the highest level of fiscal measures of $13.3 \%$ of GDP.

All these measures aim to ensure the necessary resources to overcome the crisis for the population and companies, and for the latter, the main objective is to support the corporate cash flow (Figure 7).

Figure 7. Issues resulting from the lack of cash flow

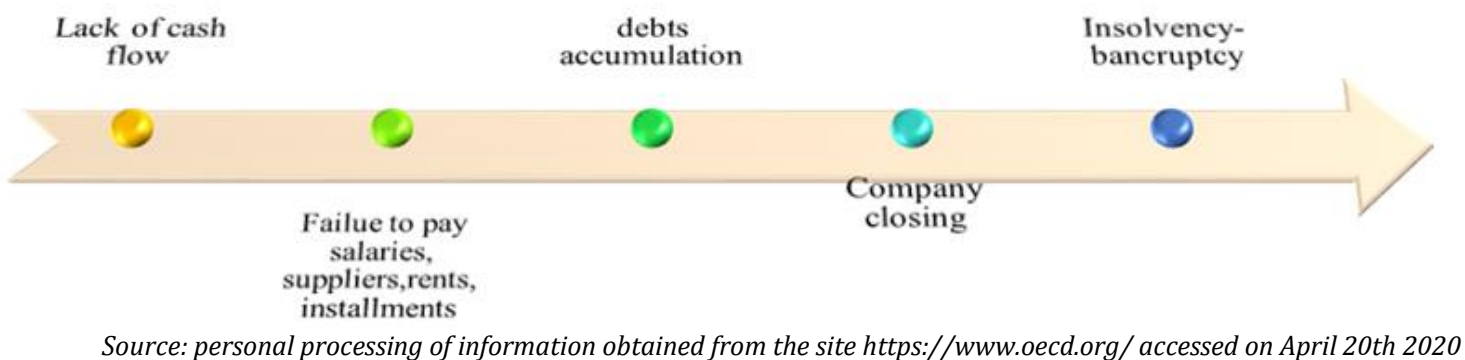

Just to ensure the conduct of companies' activities during the crisis, the capital infusions listed above were made. However, they refer to the maintenance of the related activities since the onset of the COVID Crisis and do not take into account those companies that already had difficulties, or in March 2020 moment, were already insolvent/ bankrupt. disrupted.

It is difficult for economic activity to return to pre-crisis levels if fiscal measures are abruptly

The increase in unemployment can continue if the lockdown is extended, companies can be closed or they can reach insolvency-bankruptcy, the domino effect can appear for companies forming a network; disruption of employee-firm-partner flows takes time to be restored.

Inability to pay bank instalments, both for companies and individuals, can lead to the crisis extension into a financial one. However, I have noticed that many countries have focused on reinsuring loans granted during this period, precisely to counteract the effects of the economic crisis and to possibly reverse its tendency to turn into a financial crisis.

Developing countries that have high levels of public debt, foreign currency loans, which undermine fiscal and monetary policy need to withstant economic challenges - such states are facing the devaluation of national currencies. This is where the role of national banks of those countries comes in to keep the exchange rate constant and to avoid their currency depreciation.

We revert to the importance of alleviating the lack of liquidity for companies and keeping jobs for employees as the main levers for mitigating the effects of the crisis. 
Monetary policy can help the most by providing sufficient liquidity in the market. Banks can use repo transactions (NBR, 2020) -i.e. transactions by which commercial banks obtain funds from national banks for a predetermined period and these financial resources are rerouted to companies.

Of course, for most countries, securing these funds for the implementation of tax facilities is done in part by means of loans.

In the short term, public debt has a positive impact on economic growth, but the extent of this growth depends on the contents of the fiscal-budgetary policy adopted. Measures boosting public investment and private consumption have a significant impact on economic activity, while taxes, grants have a lower incidence of subsidies, in fact changing the income level of businesses and individuals and not consumption and investment.

The long-term effects of increasing public debt and deficits are negative because national savings are reduced, which has the effect of raising interest rates -cutting down investments - lower labour costs and decline of innovation (Figure 8).

The decrease in the reference interest rate leads to a decrease in borrowing costs for the governments, the private sector and the population. As long as the central bank's interest rate is as close as possible to zero, the cost of government debt to the central bank will be minimal.

In case this crisis continues - and probably will, from an economic point of view, the risk of insolvency of some companies will be foreshadowed by the lack of liquidity.

This aspect differs from one field of activity to another, depending on the impact the crisis has had on some activities, or rather, that the impact the lockdown has had on fields such as tourism, air transport, restaurants. Many of these companies are medium- or small-seized, their access to funding sources being lower, especially if the fiscal measures do not meet their needs.

Figure 8. Negative effects of rising public debt in a long term

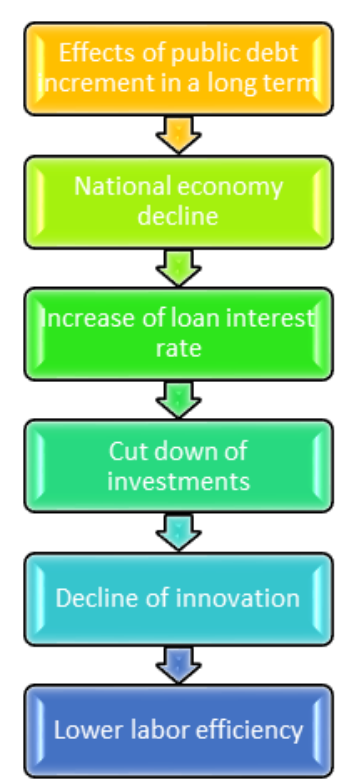

Source: Cerna, S. (2020). Consecinte economice ale datoriei publice, April 8th 2020, available at

http://www.contributors.ro/economie/consecin\%C8\%9Be-economice-ale-datoriei-publice/, accessed on June 5th 2020.

Hence the conclusion that such measures should be directed at fields most affected by the lockdown and especially at small and medium-sized firms whose financial resources are limited and the risk of insolvency and bankruptcy is high.

\section{Conclusion}

Extending the payment deadlines of taxes and fees, without generating additional costs (consisting of interest and penalties) is in fact the equivalent of an interest free loan for companies, which is much easier than taking a bank loan.

The temporary reduction of some taxes or their elimination for some types of business can be taken into account.

Postponing VAT payment deadline is a simple way to ease the liquidity pressure.

However, these tax reduction measures - the level of which can be changed, reduced, eliminated must be part of a comprehensive tax system, so that their consequences on the system are carefully correlated with a balance between sustainability and efficiency. 
Supposing the crisis is to continue, technical unemployment should be maintained, but in the form of a social contribution, with a lower level, possibly. Thus, public expenses with social assistance will run for a long time and their level will remain high.

Compliance with fiscal duties may be declining in times of crisis. Taxpayers will move away from paying tax obligations, with companies preferring to pay salaries, for example, instead of VAT, which can be especially be the case if there is no adequate or properly targeted tax facilities - which will lead to a considerable decrease in revenues to the state and social contributions budget.

The recovery from the crisis should be gradual the measures already taken should be evaluated in order to stimulate economic dynamism.

In order to avoid, for instance, the reduction of the labour market, technical unemployment should be assessed and maintained only in the fields where activity cannot be resumed (tourism, air transport, restaurants). Also, extended support for companies could have the effect of "zombie" companies that would not have survived anyway without such action. (OECD)

Giving up, for example, extending debt payment deadlines must consider avoiding accumulation of debts during the recovery period, or even compromise the companies' attempt to get out of the crisis in the recovery period.

Taxes that have been suspended during the crisis, of the lockdown, i.e. for 2 months on the average, in EU countries, could be paid on the basis of a deferred plan, dividing the payable amounts over several months, with fixed payment amounts that overlap with monthly payment obligations. Of course, such plan should not be imposed, but provided to those companies that request it. The recovery from the crisis must be made, according to the website OECD (2020a), depending on the specifics of each economy, but the recovery and initial measures must coexist in order to ensure an appropriate framework for the return to the "afloat" condition.

\section{References}

1. Bloomberg Tax\&Accounting (2020). International Tax - Direct Taxes, Coronavirus Roadmap, available at https://aboutbtax.com/PH8, accesat on June 8th 2020.

2. Bloomberg Tax (2020). Another Round of Virus-Linked Tax Relief Coming in Czech Republic, Another Round of Virus-Linked Tax Relief Coming in Czech Republic, March 23th 2020, available at https://news.bloombergtax.com/daily-tax-report-international/anotherround-of-virus-linked-tax-relief-coming-in-czech-republic, accessed on June 5th2020.

3. Cerna, S. (2020). Consecințe economice ale datoriei publice, April 8th 2020, available at http://www.contributors.ro/economie/consecin\%C8\%9Be-economice-ale-datoriei-publice/, accessed on June 5 th 2020.

4. Country Economy (2020). GDP - Gross Domestic Product, Country GDP available at https://countryeconomy.com/gdp, accessed on June 5 th2020.

5. DPA (2020). A wave of bankruptcies is coming in Europe, The Economist, May 16 th 2020 edition, available at https://www.economist.com/business/2020/05/16/a-wave-of-bankruptcies-is-coming-in-europe, accessed on June 30th 2020.

6. Eurostat (2020a). Euro area unemployment at 7.4\%, 75/2020 - 30 April 2020, available at https://ec.europa.eu/eurostat/documents/2995521/10294732/3-30042020-CP-EN.pdf/05df809c-7eb8-10c7-efcf-35325c84f56e accessed on May 20th 2020.

7. Eurostat (2020b). Eurostat, news release at https://ec.europa.eu/eurostat/documents/2995521/10294732/3-30042020-CP-EN.pdf/05df809c-7eb8-10c7-efcf-35325c84f56e, accessed on May 20th 2020.

8. Eurostat (2020c). Reporting of Government Deficits and Debt Levels, available at https://ec.europa.eu/eurostat/documents/1015035/10718819/DE-2020-04.pdf/2d8f00f2-9a31-860b-864f-f022e030b5ec, accessed on April 15th2020.

9. Eurostat (2020d). EDP notification table, available at https://ec.europa.eu/eurostat/web/government-finance-statistics/excessivedeficit-procedure/edp-notification-tables, accessed on May 16 th2020.

10. Eurostat (2020e). Reporting of Government Deficits and Debt Levels, available at https://ec.europa.eu/eurostat/web/governmentfinance-statistics/excessive-deficit-procedure/edp-notification-tables, accessed on June 5th 2020.

11. Florea, M. (2020). Covid-19: Guvernul adopta masuri fiscal-bugetare cu impact de 2\% din PIB, pentru sprijinirea mediului de afaceri, Manager.ro - Rentrop\&Straton, available at https://www.manager.ro/articole/ultima-ora-93/covid-19-guvernul-adopta-masurifiscal-bugetare-cu-impact-de-procente-din-pib-pentru-sprijinirea-mediului-de-afaceri-102984.html, accessed on June 5th 2020.

12. Foreman-Peck, E. (2020a). The changes covid-19 is forcing on to business, The Economist, April 11th 2020 edition, available at https://www.economist.com/briefing/2020/04/11/the-changes-covid-19-is-forcing-on-to-business, accessed on May 11th 2020.

13. Foreman-Peck, E. (2020b). Do low-trust societies do better in a pandemic?, The Economist, May 16 th 2020 edition, available at https://www.economist.com/europe/2020/05/02/do-low-trust-societies-do-better-in-a-pandemic, accessed on June 30th 2020.

14. Gouvernement (2020). Declaration on Emergy Measures for Local Autorities, available at https://www.gouvernement.fr/suivre-lactualite-du-premier-ministre, accessed on May 29th 2020.

15. International Labour Organisation (ILO). (2020a). Country policy responses, available at https://www.ilo.org/global/topics/coronavirus/country-responses/lang--en/index.htm accessed on June 5th2020.

16. International Labour Organisation (ILO). (2020b). Country policy responses, available at https://www.ilo.org/global/topics/coronavirus/country-responses/lang-en/index.htm\#DK, accessed on April 25 th 2020.

17. International Labour Organisation (ILO). (2020c). Country policy responses available at https://www.ilo.org/global/topics/coronavirus/country-responses/lang--en/index.htm\#AT, accessed during the period May 1st-June 10th 2020.

18. Markets Insider (2020). Germany is seeking a fresh $\$ 112$ billion coronavirus stimulus package, just days after the EU launched its historic $\$ 826$ billion plan, available at https://markets.businessinsider.com/news/stocks/germany-economy-112-billion-coronavirusstimulus-rescue-plan-2020-6-1029271636, accessed on June 5th 2020.

19. IV (2020). Industry welcomes the prospect of a revival of the business location, available at https://www.iv.at/de/news/ivnews/2020/industrie-begrusst-perspektive-fur-wiederhochfahren-des-wirtscha, accessed on April 25 th 2020. 
20. National Bank of Romania (NBR), (2020). Banca Centrală Europeană și Banca Națională a României au agreat implementarea unei linii repo pentru furnizarea de lichiditate în euro, available at https://bnr.ro/page.aspx?prid=17896, accessed on June 3rd 2020.

21. OECD (2020a). Tackling coronavirus (COVID-19). Contributing to a global effort, available at http://www.oecd.org/coronavirus/en/, accessed on April 20th -June 7th 2020.

22. OECD (2020b). Policy Tracker browse by contry, available at https://www.oecd.org/coronavirus/country-policy-tracker/ accessed during the period April 2nd - June 10th 2020

23. OECD (2020c). The European Economy before and after the pandemic, available at https://issuu.com/oecd.publishing/docs/academie_notre_europe_avril_2020?issuu_product=document_page\&issuu_context=action\&iss u__cta=save_publication, accessed during the period April 10th - April 30th2020.

24. Parkins, D. (2020). Britain has the wrong government for the covid crisis, The Economist, June 18 th 2020 edition, available at https://www.economist.com/leaders/2020/06/18/britain-has-the-wrong-government-for-the-covid-crisis, accessed on 25 June 2020.

25. Public Finance Minister (PFM), (2020). Norme de aplicare pentru IMM Invest, available at https://www.mfinante.gov.ro/pagina.html?categoriebunuri=covid19\&pagina=acasa, accessed on June 3rd2020.

26. Trading Economics (2020). Hungary GDP available at https://tradingeconomics.com/hungary/gdp, accessed on June 2nd 2020.

27. UNRR (2020). The State Tax revenues will be lower than expected, available at https://unrr.cz/danove-prijmy-statu-budou-nizsi-nezse-cekalo-vybor-pro-rozpoctove-prognozy-vidi-predikci-mf-jako-optimistickou/, accessed on April 25th 2020.

28. UPB (2020). Memorandum of the Chairman of the PBO on Bill AC 2461 ratifying Decree Law 8 April 2020 n. 23 (the Liquidity Decree), available at http://en.upbilancio.it/memorandum-of-the-chairman-of-the-pbo-on-bill-ac-2461-ratifying-decree-law-8-april-2020-n23-the-liquidity-decree/\#more-2731, accessed on April 30th2020. 